\title{
Sulphured Polyacrylonitrile Composite Analysed by in operando UV-Visible Spectroscopy and 4-electrode Swagelok Cell
}

\author{
Robert Dominko, ${ }^{1}$ Manu U. M. Patel, ${ }^{1}$ Marjan Bele ${ }^{1}$ and Stane Pejovnik ${ }^{2}$ \\ ${ }^{1}$ National Institute of Chemistry, Hajdrihova 19, SI-1000 Ljubljana \\ ${ }^{2}$ Faculty for Chemistry and Chemical Technology, University of Ljubljana, Večna pot 113, 1000 Ljubljana, Slovenia \\ * Corresponding author: E-mail: robert.dominko@ ki.si \\ Tel: +38614760362
}

Received: 19-02-2016

\begin{abstract}
In the memory of Janez (Janko) Jamnik, respected scientist, excellent coworker and leader and friend we will never forget
\end{abstract}

\begin{abstract}
The electrochemical characteristics of sulfurized polyacrylonitrile composite (PAN/S) cathodes were compared with the commonly used carbon/S-based composite material. The difference in the working mechanism of these composites was examined. Analytical investigations were performed on both kinds of cathode electrode composites by using two reliable analytical techniques, in-situ UV-Visible spectroscopy and a four-electrode Swagelok cell. This study differentiates the working mechanisms of PAN/S composites from conventional elemental sulphur/carbon composite and also sheds light on factors that could be responsible for capacity fading in the case of PAN/S composites.
\end{abstract}

Keywords: Polyacrylonitrile, sulphur, batteries, operando, UV-Vis

\section{Introduction}

Sulphur (S) is considered as a potential cathode material because of its high theoretical capacity $1672 \mathrm{mAh}$ $\mathrm{g}^{-1}$ and energy density $2500 \mathrm{Wh} \mathrm{kg}^{-1}$. The high capacity is based on the conversion reaction of elemental sulphur to form the lithium sulphide $\left(\mathrm{Li}_{2} \mathrm{~S}\right)$ by reversibly incorporating two electrons per $\mathrm{S}$ atom. This is an order of magnitude higher compared to current commercial lithium ion technology. In addition to this, lithium-sulphur ( $\mathrm{Li}-\mathrm{S})$ batteries have many advantages; $S$ is a waste material of the petroleum industry, which makes it an inexpensive raw material; $\mathrm{Li}-\mathrm{S}$ can be operated under wide range of temperatures; systems using it are considered safe and environmentally friendly. ${ }^{1-4}$

Despite the advantages mentioned above, the system does have major shortcomings that prevent it from being commercialised. Sulphur is a highly insulating element and needs conductive electron additives, such as carbon black, to make it feasible as an electrode material. That decreases the practical energy density that can be obtained from the system. Additionally, the intermediate lithium polysulphides formed during battery cycling are soluble in the electrolyte and can diffuse or migrate to the negative electrode, which induces the socalled shuttle mechanism within the electrochemical cell. The electrochemical conversion of sulphur to $\mathrm{Li}_{2} \mathrm{~S}$ involves repetitive dissolution and deposition of reactive species, which passivates both electrodes, leading to a significant increase in internal resistance of the battery. Furthermore, there has been a lack of understanding of the system, which has many complicated equilibrium species and radicals arising due to the dissolution of lithium polysulfides in the liquid electrolyte. All these factors have led to underperforming $\mathrm{Li}-\mathrm{S}$ batteries. ${ }^{5-7}$

To overcome these obstacles, recent efforts have been focused on the reduction of the adverse effects caused by the shuttling of polysulphides by developing new types of $\mathrm{S}$ cathodes. ${ }^{8-9}$ The most common type of cathodes in use today include carbon nanotubes/S composites, ${ }^{10}$ graphene/S composites, ${ }^{11-15}$ conductive polymer/S 
composites, ${ }^{16-22}$ porous oxide additive composites, ${ }^{23}$ and nanostructured $\mathrm{Li}_{2} \mathrm{~S}$ cathodes. ${ }^{24}$ The basic electrochemical reaction taking place in most of these carbon/S based electrode composites is the same, i.e. elemental $\mathrm{S}$ is reduced to lithium polysulphides of different chain lengths during the discharge followed with a precipitation of $\mathrm{Li}_{2} \mathrm{~S}$ as end discharge product. While charging, the reverse process of discharge takes place, in which most of the lithium polysulphides are oxidised back to elemental sulphur.

A different mechanism was proposed for the poly(acrylonitrile)/sulphur (PAN/S) based cathode materials which are typically synthesised by heating a mixture of polyacrylonitrile (PAN) and S at moderate temperatures. ${ }^{21,22,25}$ This class of materials has been widely investigated due to their advantages in terms of high capacity, cycling stability and compatibility with conventional electrolytes used in Li-ion batteries. ${ }^{21,22,25-27}$ However, the synthesis process, the material structure, and the working principle of these cathode composites remain under debate and need further understanding. ${ }^{28-31}$

In this study, we analyse the PAN/S composite via the use of analytical techniques, such as operando mode UV-Vis spectroscopy and 4-electrode modified Swagelok cell. We compare electrochemical behaviour with results obtained from the cathode composites in which sulphur is impregnated in the pores of carbon black particles. Both aforementioned analytical tools were recently used for studding mechanisms in the different $\mathrm{Li}-\mathrm{S}$ battery systems. ${ }^{32-34}$

With both techniques, we can detect soluble polysulphides responsible for the shuttle lock system in the case of using carbon black/sulphur composite, while we prove the absence of formation of polysulphides in the case of PAN/S composites.

\section{Experimental}

\section{a) Preparation of composites}

The polyacrylonitrile (PAN) and sulphur were obtained from Sigma-Aldrich. A mixture of PAN and sulphur in a weight.\% ratio of 30:70 was ball milled for $30 \mathrm{~min}$ utes at $300 \mathrm{rpm}$ and heat treated in a ceramic crucible in a quartz tube at $300{ }^{\circ} \mathrm{C}$ under argon atmosphere for 6 hours. After cooling to room temperature, a sample with a black colour was recovered. In the same way, carbon black (Vulcan) and sulphur were taken in a weight ratio of 60:40, respectively, and ball milled for $30 \mathrm{mins}$ at $300 \mathrm{rpm}$. The ball milled mixture was heated to $155^{\circ} \mathrm{C}$ under argon atmosphere for 6 hours. Both composites were checked using CHNS elemental analysis. The results of the PAN/S composite showed that sample contains C: $38.73 \mathrm{wt} . \%, \mathrm{~S}$ : $40.25 \mathrm{wt} . \%$, and N: $14.67 \mathrm{wt} . \%$; the remainder is hydrogen. The carbon/S composite showed $40 \mathrm{wt} . \%$ of sulphur in the composite.

\section{b) Preparation of electrode and electrochemical cha- racterization:}

Electrodes from the composites were prepared by making a slurry of composite, polytetrafluoroethylene (Sigma-Aldrich) and carbon black (PRINTEX XE2) in a mass ratio of 80:10:10 in isopropanol solvent. The slurry was then cast on the surface of aluminium foil, using the doctor blade technique. Dried electrodes were used to assemble a coffee bag batteries in an argon-filled glove box, where $1 \mathrm{M}$ Lithium Bis(Trifluoromethanesulfonyl)Imide (LiTFSI) in sulfolane was used as an electrolyte and pure lithium metal was used as an anode electrode. The sulphur loading was $1.0-1.5 \mathrm{mg} / \mathrm{cm}^{2}$ among the electrodes. Electrodes were separated by a glass fibber separator, and the amount of electrolyte used in all the batteries was normalized per active mass; it was 60 $\mathrm{mL}$ per $\mathrm{mg}$ of S. Galvanostatic cycling was performed at room temperature by using a Bio-Logic VMP3 instrument with a current density of $167.5 \mathrm{mAg}^{-1}$ in the potential window between $3 \mathrm{~V}$ and $1.5 \mathrm{~V}$ for carbon/S composites and $3 \mathrm{~V}-1 \mathrm{~V}$ for the PAN/S composite electrode. The coulombic efficiency was calculated as a ratio between discharge capacity and charge capacity obtained from the previous charge.

\section{c) Operando mode measurements}

In the case of UV-Vis measurements, electrodes prepared for the electrochemical characterisation were used. The battery assembly, electrochemical and UV-Vis measurements were carried out in the manner as explained by Patel et al. ${ }^{32}$

The composites from PAN/S and carbon/S along with carbon black (Printex XE2) were taken in a 90:10 wt.\% ratio and mixed to obtain powdered electrode materials. A controlled amount of the powder was taken in the 4-electrode Swagelok cell and the battery was assembled and cycled as explained by Dominko et al. ${ }^{33}$ The quantity of electrolyte was quantified to $60 \mu \mathrm{L}$ per $\mathrm{mg}$ of $\mathrm{S}$ in the cathode composite.

\section{Results and Discussion}

Figure 1 shows the thermogravimetric analysis of PAN, carbon/S and PAN/S samples performed in air atmosphere. All three samples can be clearly differentiated from each other in terms of their weight loss. The PAN polymer shows a degradation process in the temperature range of $270-600{ }^{\circ} \mathrm{C}$ with more than $60 \mathrm{wt} . \%$ loss. The carbon/S sample shows $40 \mathrm{wt} . \%$ loss that corresponds to elemental $\mathrm{S}$ in the sample. Meanwhile, the PAN/S sample did not show a similar kind of weight loss, as CHNS analysis indicated a presence of $40 \mathrm{wt} . \%$ $\mathrm{S}$ in the sample. The PAN/S shows slow degradation process at a relatively higher temperature of above $300{ }^{\circ} \mathrm{C}$ with less than $8 \mathrm{wt} . \%$ loss even after reaching 


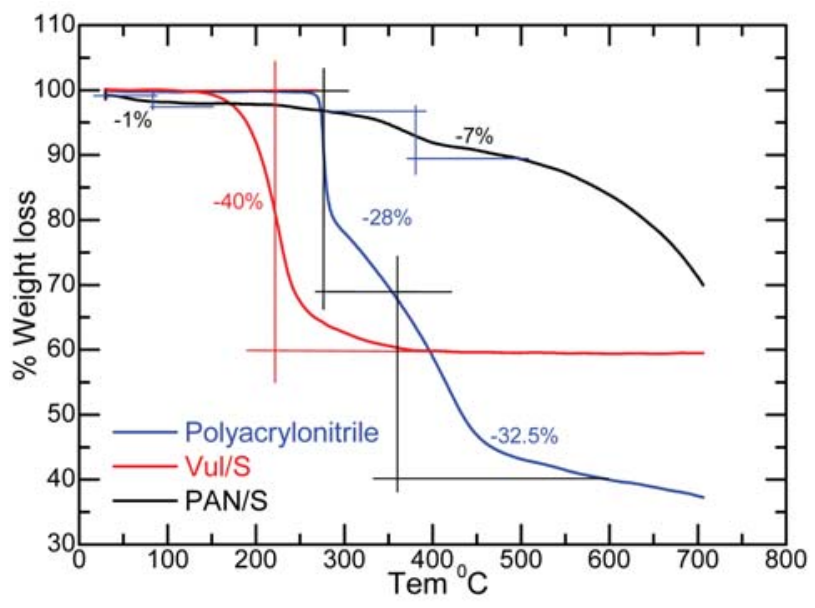

Figure 1. TGA plots of PAN (blue), carbon/S (red) and PAN/S composite (black).

$700{ }^{\circ} \mathrm{C}$, which indicates that the structure of the composite was quite stable and complex. It must be remembered that no posttreatment of the PAN/S composite in order to remove excesses of the elemental $\mathrm{S}$ was performed. Further proof for the absence of elemental $\mathrm{S}$ in the PAN/S composite can be found in the voltage profiles of the battery (Figure 2a) where a typical two plateaus characteristic for sulphur conversion into polysulphides and $\mathrm{Li}_{2} \mathrm{~S}$ is not observed.

The PAN/S composite starts to discharge at a voltage of around $1.8 \mathrm{~V}$ in the first cycle and the voltage plateau shifts to $2.1 \mathrm{~V}$ in the following cycles. The presented electrochemical behaviour is different in comparison to conventional $\mathrm{Li}-\mathrm{S}$ battery behaviour obtained from composite containing $40 \mathrm{wt} . \%$ of elemental S, which starts to discharge at $2.4 \mathrm{~V}$ for the first plateau, followed by the second discharge plateau at approximately $2.0 \mathrm{~V}$ (Figure $2 b)$. These first sets of measurement suggest the absence of elemental S in the PAN/S sample.

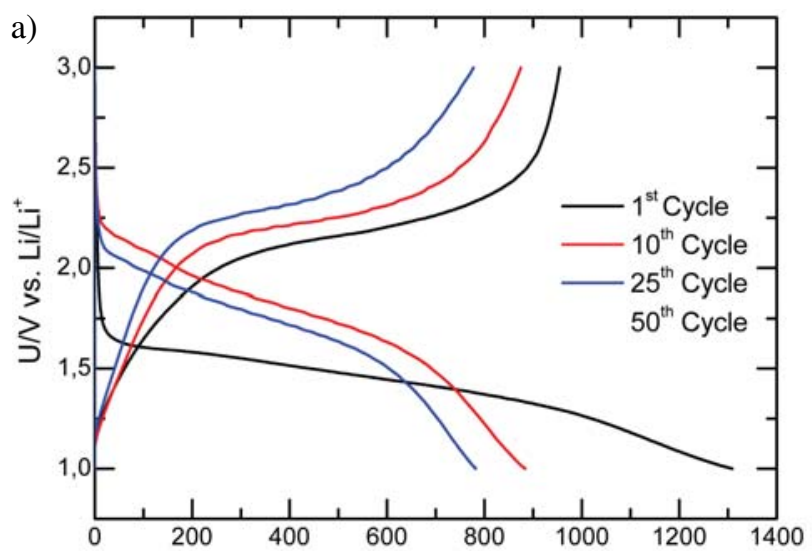

The results of the galvanostatic cycling for both composites are shown in Figure 3. The performance of PAN/S composite outperforms the carbon/S composite in terms of capacity retention, while the capacity fading was similar in both cases. Reasons for constant capacity fading can be diverse. One potential reason is a non-stable lithium surface exposed to the electrolyte or cathode stability in terms of wiring. Out from shape of the galvanostatic curves, a different mechanism of sulphur conversion can be expected. For that purpose, we used two operando mode analytical tools developed recently in our laboratory. ${ }^{31-33}$

At first, in-situ UV-Vis spectroscopy was applied on both composites. As is known, when lithium polysulphides are formed during the battery operation, they tend to dissolve in the electrolyte and then diffuse into the separator of the battery. This indicates that they can be detected in the separator of the battery, as they have different colours depending upon the chain length of the polysulphide. The colour of the polysulphides ranges from dark red for long chain polysulphides to green for medium

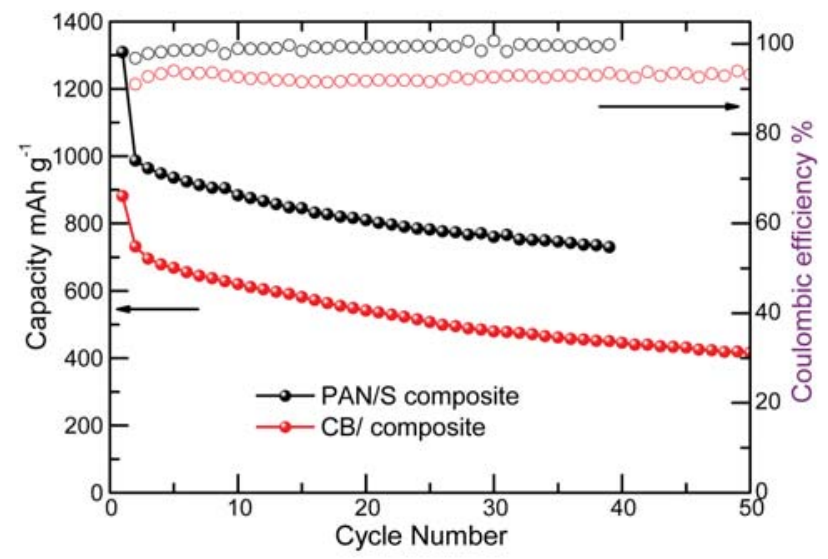

Figure 3. Discharge capacity (left axis) and coulombic efficiency (right axis) of PAN/S and carbon/S based composites for 50 cycles.

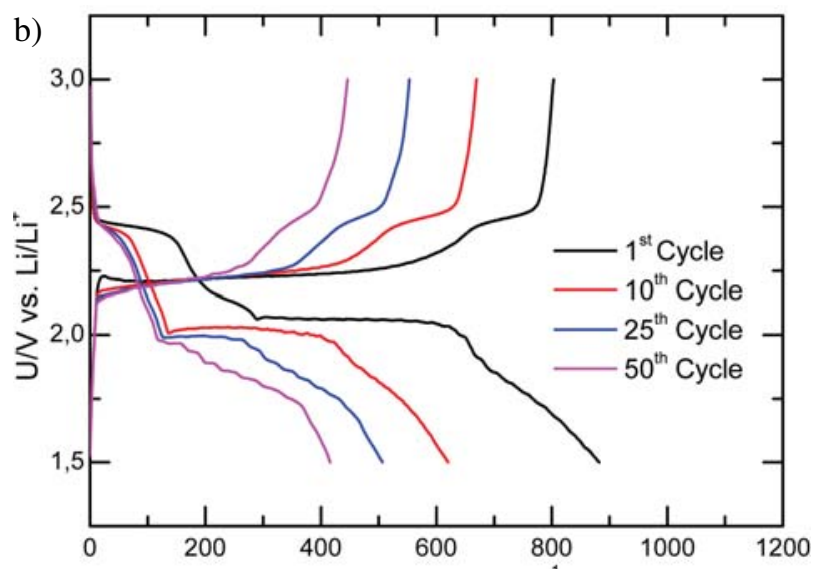

Figure 2. a) Discharge/charge capacity of the elemental PAN/S based composite in the selected cycles and b) Discharge/charge capacity of carbon/S composite in the selected cycles. 
a)

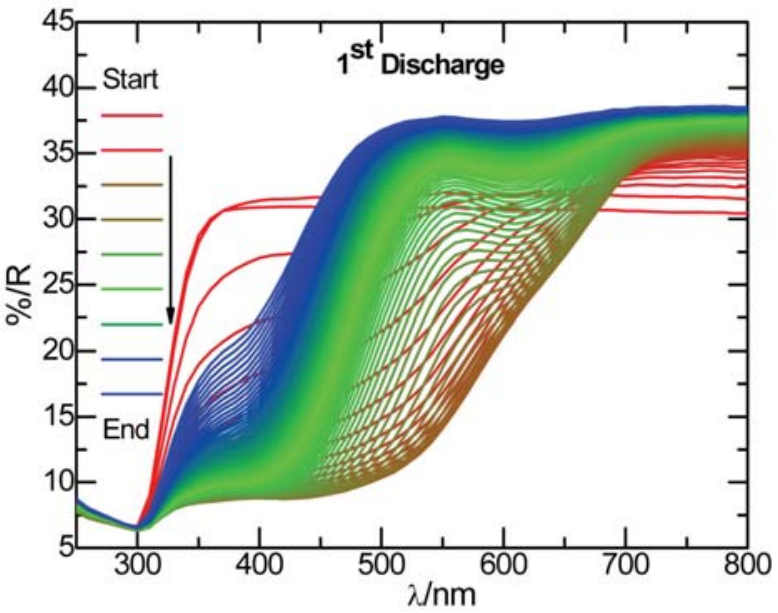

c)

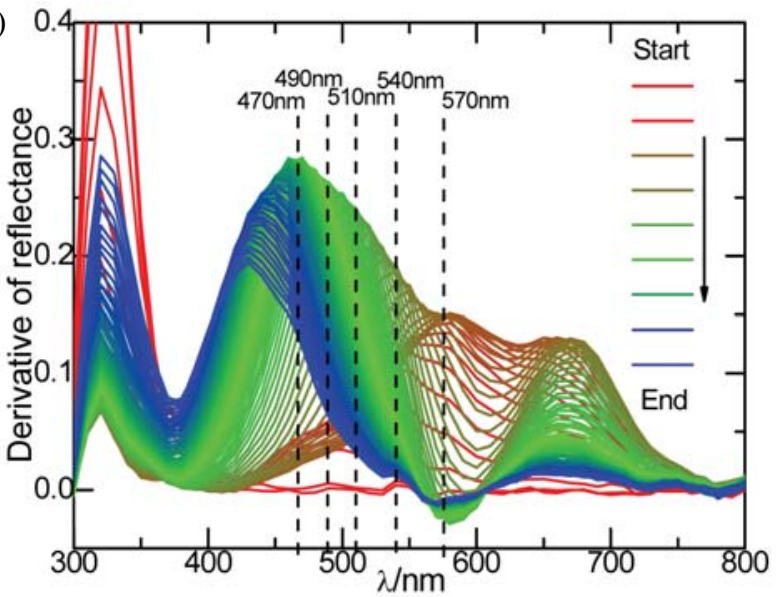

b)

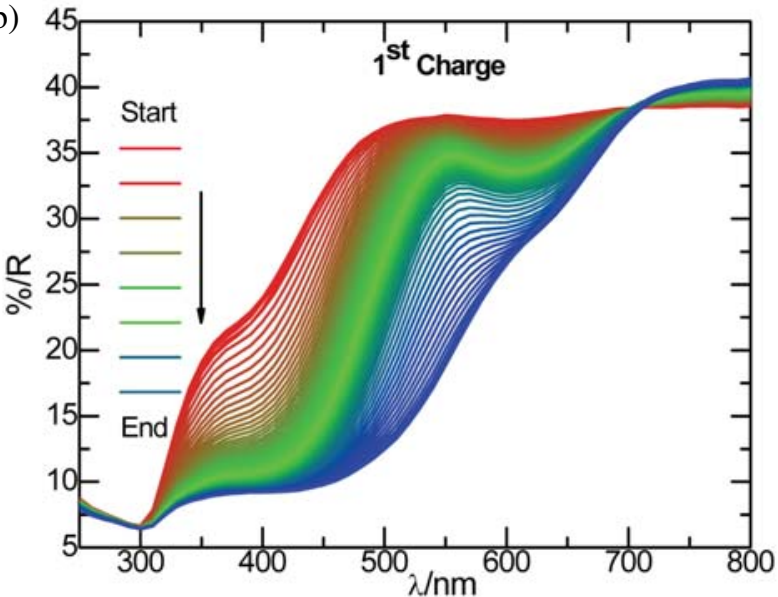

d)

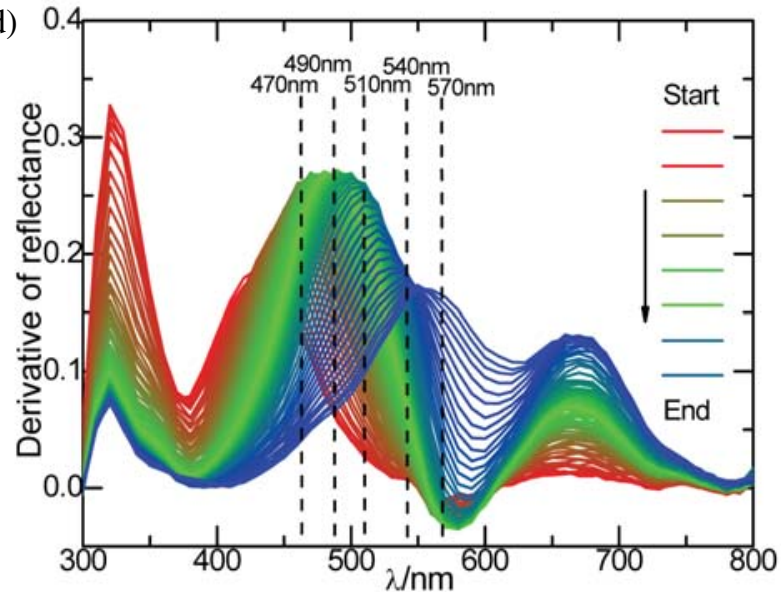

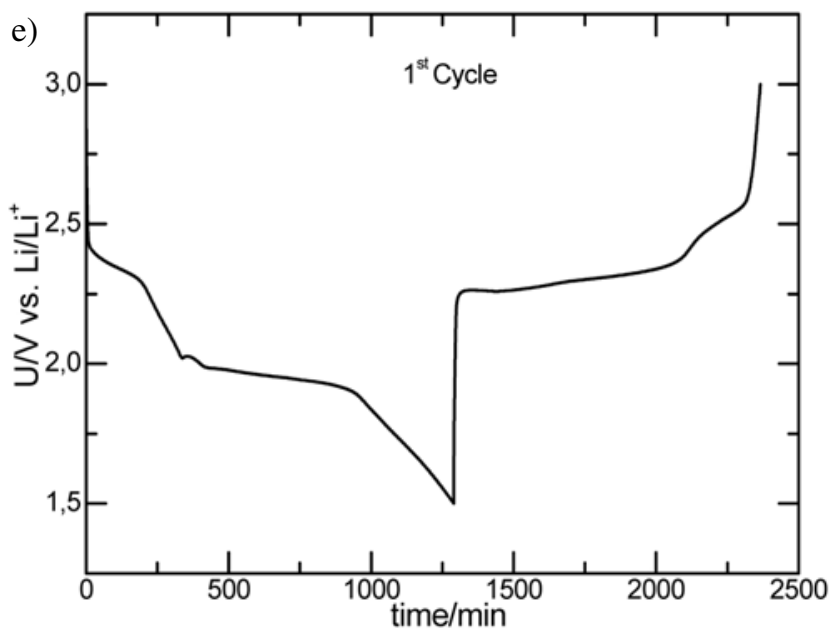

Figure 4. a, b) Obtained UV-Vis spectra from discharge and charge cycle of carbon/S composite. c, d) The first derivative of the obtained spectra during discharge and charge cycle showing shifts in the wavelength. e) The electrochemical curve of in-situ UV-VIS measurement of carbon/S composite.

and short chain polysulphides. ${ }^{32}$ By using this as a platform, the in-situ UV-Vis measurements were conducted. The obtained spectra indicate that when the carbon/S composite was used, the formation of lithium polysulphides of different chain lengths took place at different po- tentials of battery operation. In other words, during discharge the long chain polysulphides were formed at higher voltage plateau and they appear at longer wave numbers on the UV-Vis spectra. The medium and short chain polysulphides were formed at the lower voltage plateau and 
a)
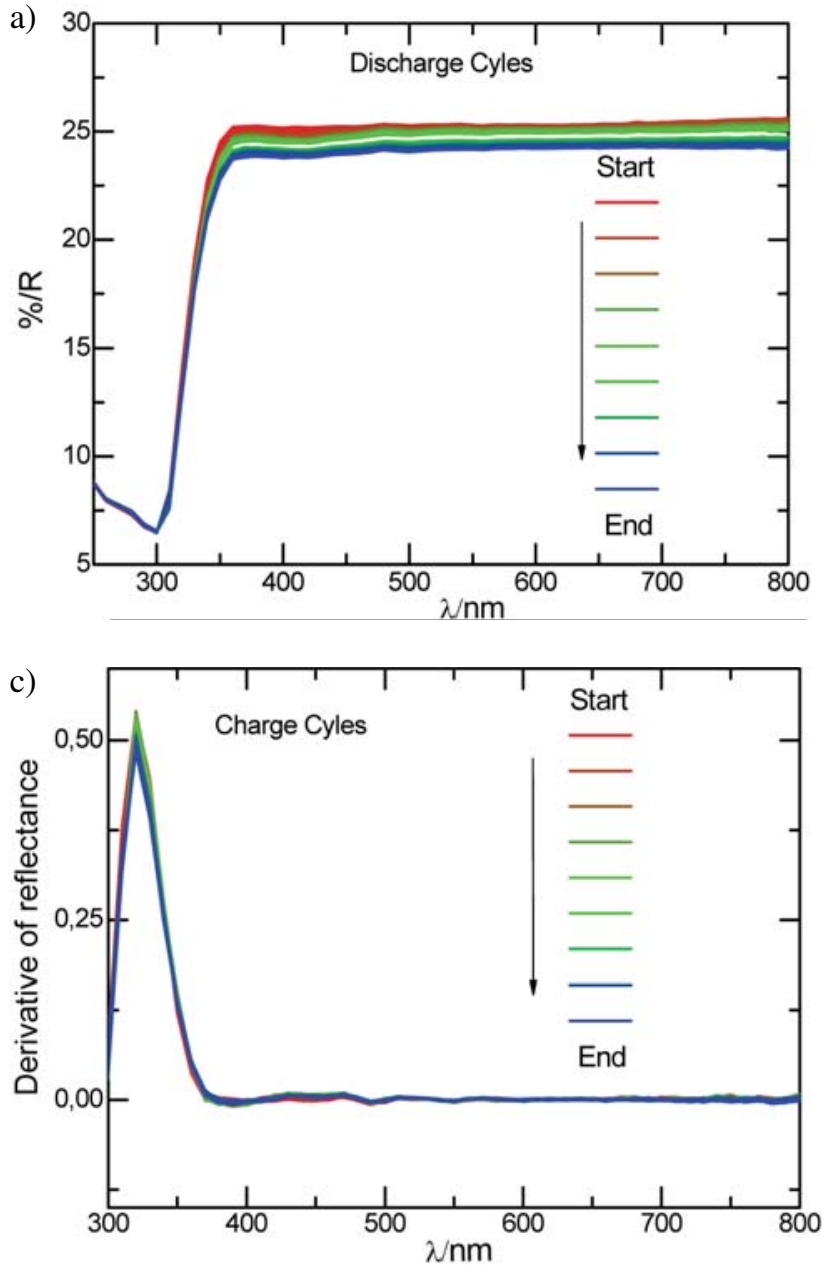

b)
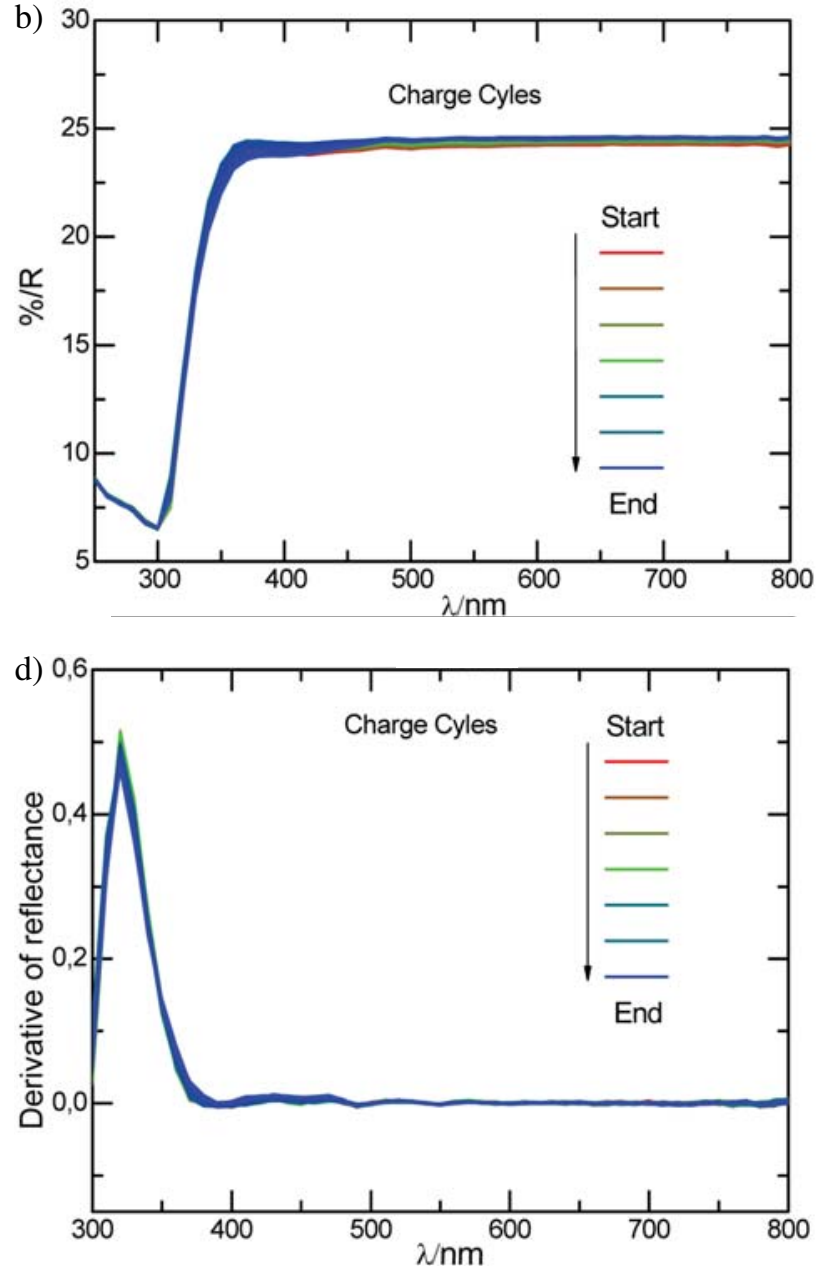

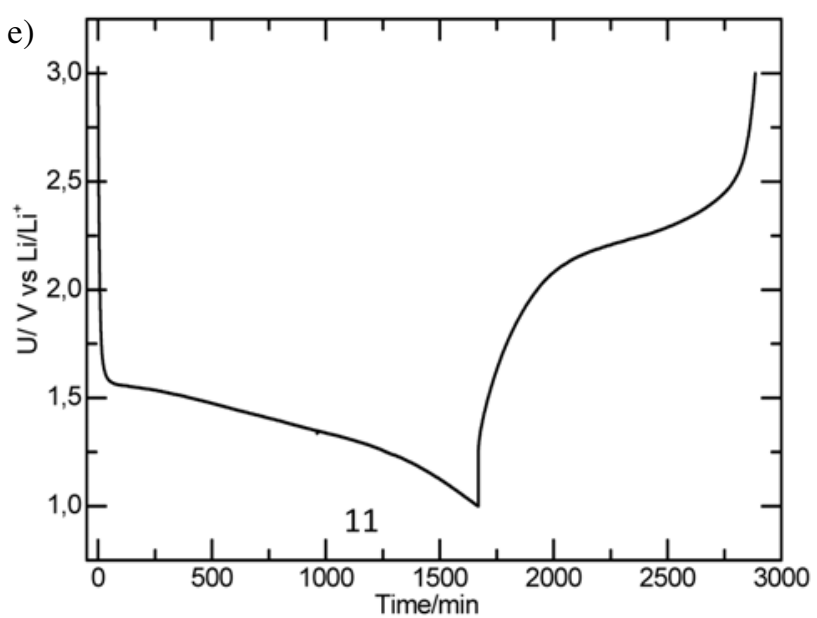

Figure 5. a, b) Obtained UV-Vis spectra from discharge and charge cycle of PAN/S composite. c, d) The first derivative of the obtained spectra during discharge and charge cycle showing shifts in the wavelength. e) The electrochemical curve of in-situ UV-VIS measurement of PAN/S composite.

appeared at shorter wave numbers in the UV-Vis spectra. While charging the battery the reverse process of discharge i.e. short chain polysulphides were formed at the beginning of the charge followed by the mid-chain and long chain polysulphides towards the end of the charge. Figu- re $4 \mathrm{a}$ and $4 \mathrm{~b}$ shows the obtained UV-Vis spectra during discharge and charge of the first cycle. Figure $4 \mathrm{c}$ and $4 \mathrm{~d}$ shows the first derivative of the obtained spectra during discharge and charge of the elemental carbon/S composite. The first derivative of the in-situ measurements clear- 
ly show that the long chain polysulphides appeared at $570 \mathrm{~nm}$, mid-chain polysulphides appeared in 510 $550 \mathrm{~nm}$ and short chain polysulphides at $430 \mathrm{~nm}$, which was a normal observation for the elemental $\mathrm{S}$ based composites.

a)
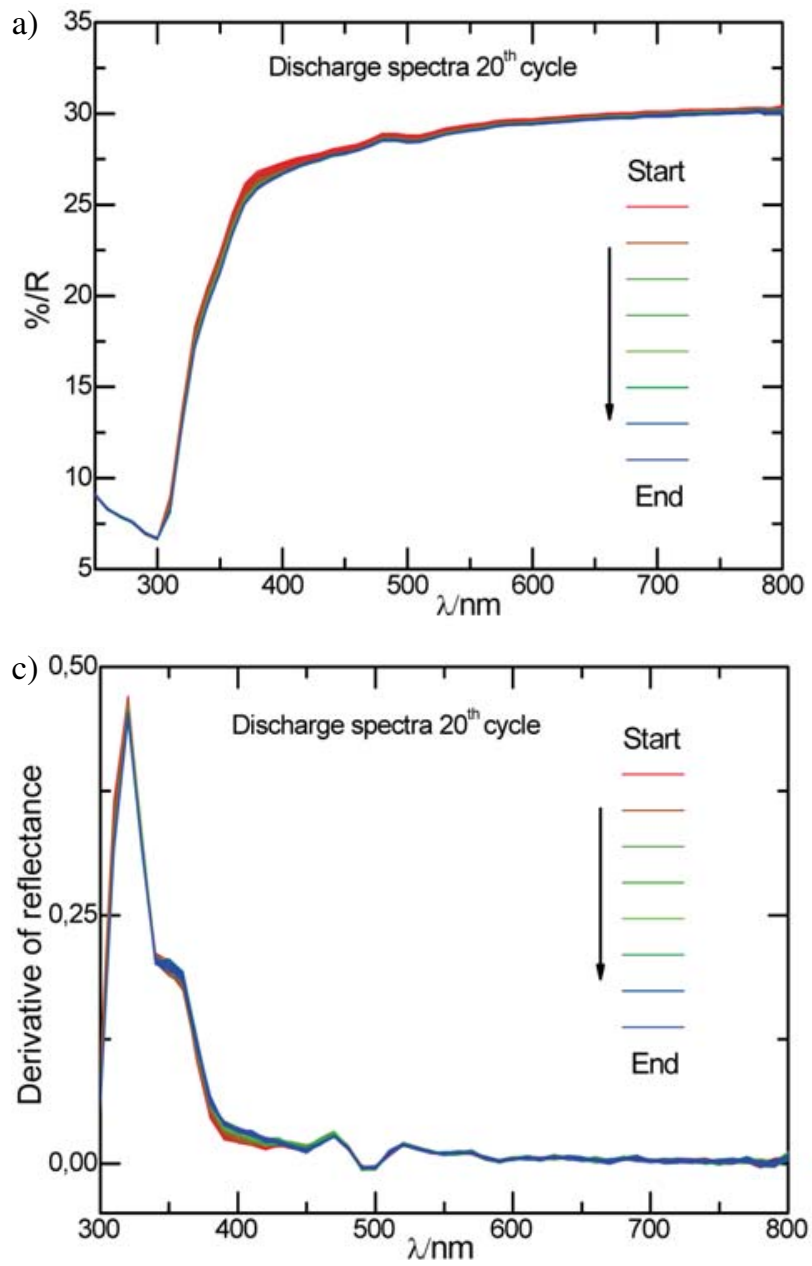

However, the interesting part arises from the in-situ UV-Vis measurements on the PAN/S composite that clearly shows the absence of any lithium polysulphides. Figure $5 \mathrm{a}$ and $5 \mathrm{~b}$ shows the obtained UV-Vis spectra during discharge and charge of the first cycle. Figure $5 \mathrm{c}$ and

b)
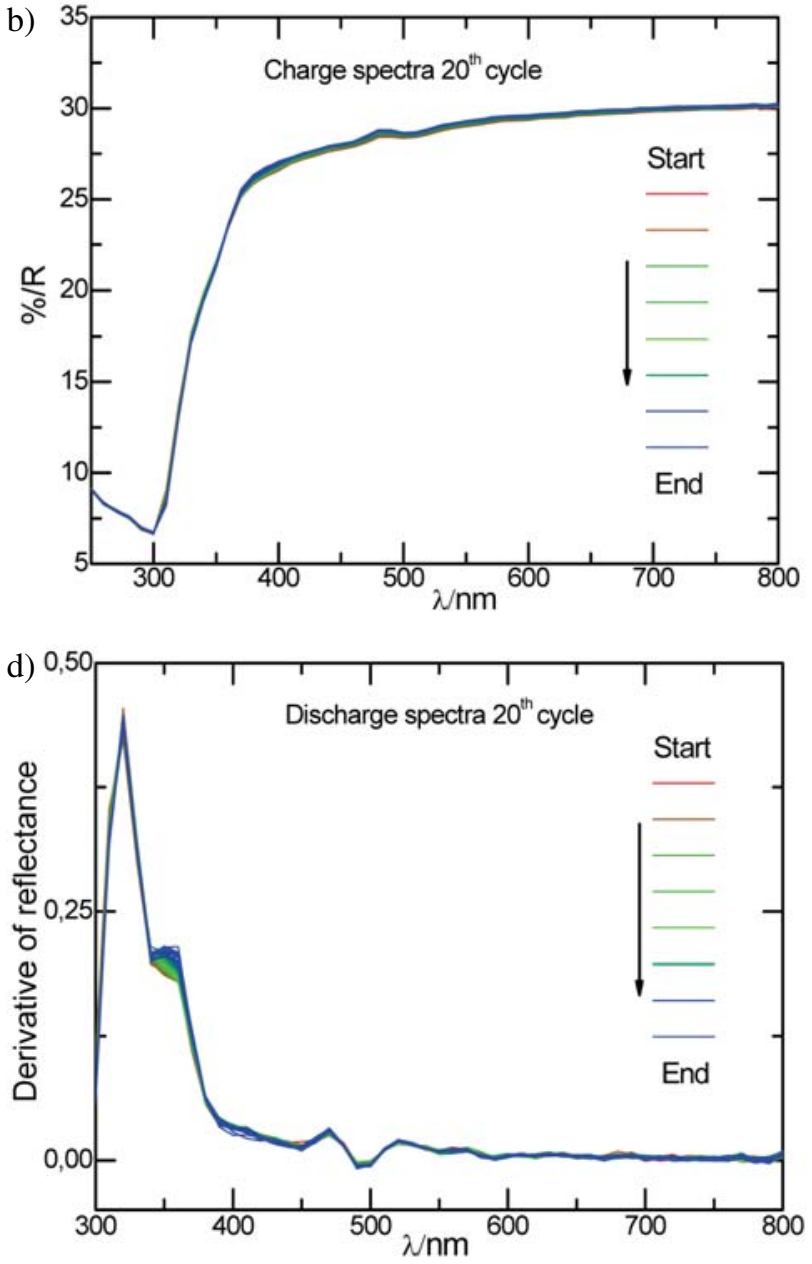

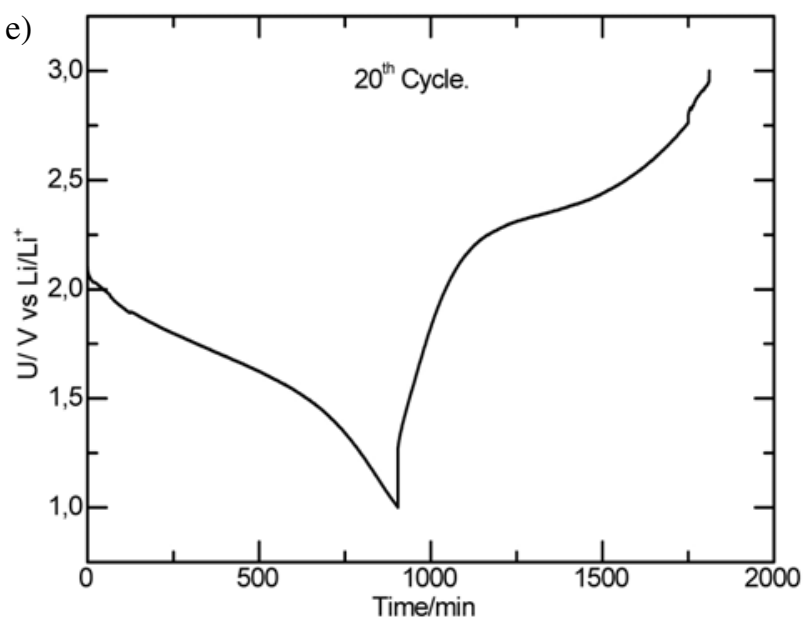

Figure 6. a, b) Obtained UV-Vis spectra from discharge and charge cycle of PAN/S composite on the $20^{\text {th }}$ cycle. c, d) The first derivative of the obtained spectra during discharge and charge cycle showing shifts in the wavelength. e) The $20^{\text {th }}$ cycle electrochemical curve of in-situ UV-VIS measurement of PAN/S composite. 
$5 \mathrm{~d}$ shows the first derivative of the spectra during discharge and charge of PAN/S composites. The scanned spectra are stable; there is no change in the absorbance position suggesting the absence of any coloured species in the electrolyte. Knowing that the polysulphides are coloured in solvents, we can exclude the formation of soluble polysulphides during the reduction and oxidation process in the battery composed of PAN/S composite. Even in the case of the first derivative there was no trace of polysulphides that could show the shift in wave number to higher wavelengths. This confirms that there was no elemental S in the composite and consequently no soluble polysulphides that can be detected in the separator of the battery.

However, Fanous et al. ${ }^{30}$ proposed that after the removal of any remaining elemental $\mathrm{S}$ in the PAN/S composites via an extraction with toluene their analysis suggested that $\mathrm{S}$ is exclusively covalently bound to carbon and not to nitrogen in the composite. They also proposed a chemical structure for PAN/S composite, which consists of a conjugated $\pi$-system. It was mentioned that the discharge profile of a cell prepared from LiTFSI in 1,3-dioxolane (DOL) and dimethoxyethane (DME) changes after the first cycle. They indicated that the voltage shifts from $1.8 \mathrm{~V}$ to $2.15 \mathrm{~V}$ in the following cycles was due to the formation of elemental $\mathrm{S}$ in
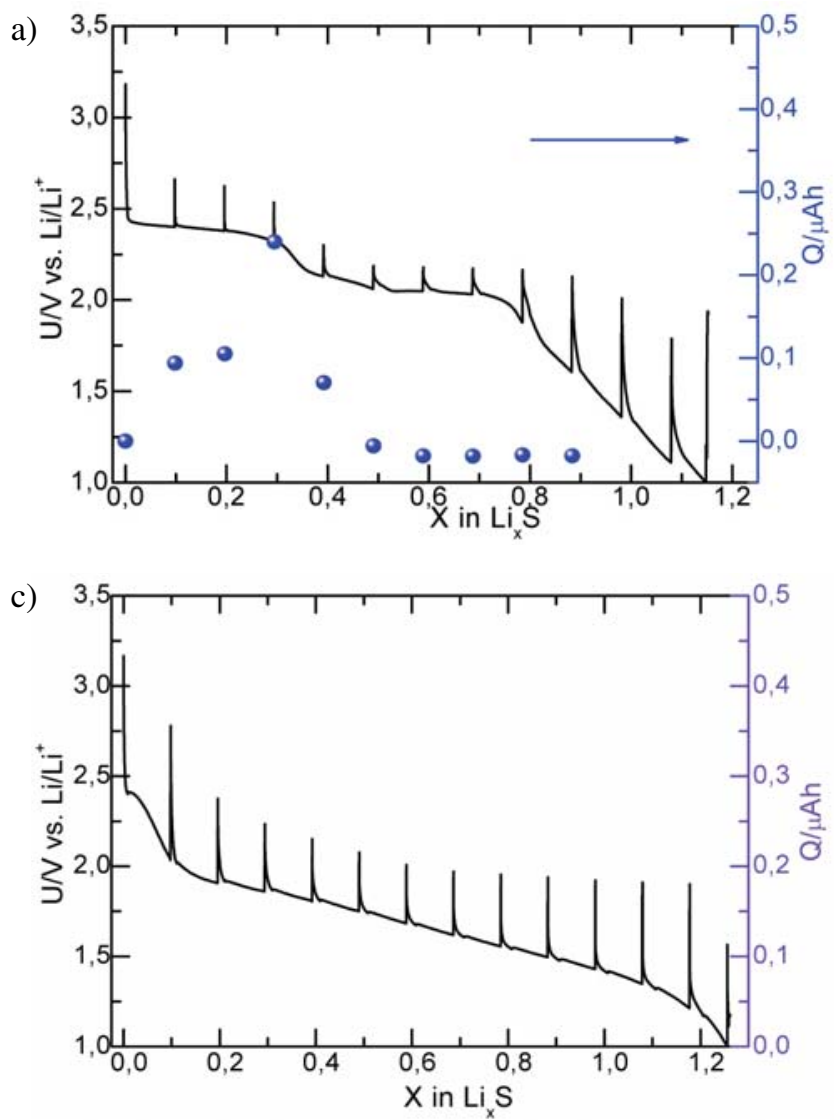

the electrode. It is expected that the reduction of S leads to the formation of polysulphides and a continuous diffusion of polysulphides, as in the case of a normal Li-S cell. In order to verify whether elemental $\mathrm{S}$ is, in fact, formed during the battery cycling, which could lead to lithium polysulphide formation, we measured a UV-Visible spectroscopy after $19^{\text {th }}$ cycles, when the voltage plateau of the discharge curve was shifted to $2.1 \mathrm{~V}$. All the parameters were kept the same while measuring the UV-Visible spectroscopy of $20^{\text {th }}$ cycle, as done for the first cycle. The obtained spectra during discharge and charge for the $20^{\text {th }}$ cycle are shown in Figures $6 \mathrm{a}$ and $6 \mathrm{~b}$ and their derivatives are presented in Figures $6 \mathrm{c}$ and $6 \mathrm{~d}$. The small difference between the measured spectra and related derivatives suggests the change of the colour in the separator, which is probably connected with a degradation process in the cell. However, due to the absence of strong colouration we can exclude the formation of elemental sulphur in the formation cycles since this should be observed as a formation of polysulphides which would give a characteristic colour in the separator.

To confirm these findings, additional analysis by using a modified 4-electrode Swagelok cell was performed. In addition to the standard Swagelok configuration, this cell has two additional perpendicular electrodes (wires)
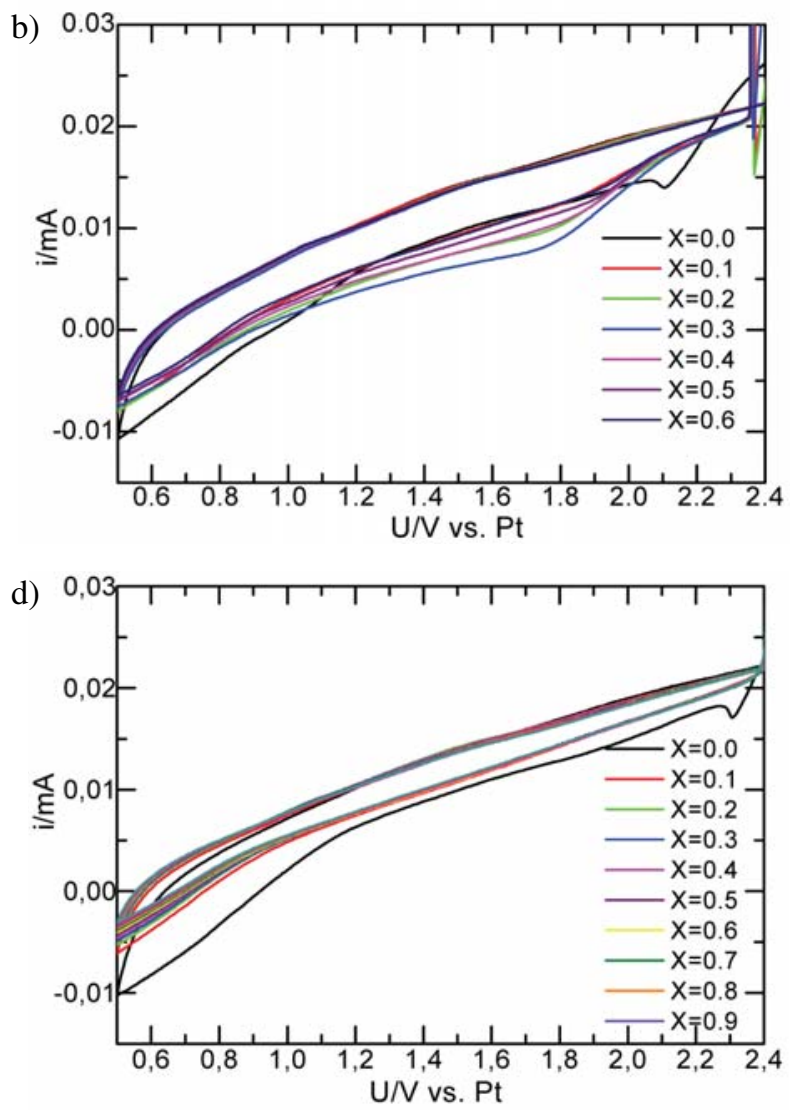

Figure 7. a) Electrochemical behaviour during the first reduction of carbon/S composite and cumulative charge obtained by the integration of individual CV scans. b) Corresponding CV scans measured for each $\Delta \mathrm{x}=0.1$ change of composition in $\mathrm{Li}_{\mathrm{x}} \mathrm{S}$. c) Electrochemical behaviour during the first reduction of PAN/S composite. d) Corresponding CV scans measured for each $\Delta \mathrm{x}=0.1$ change of composition. 
placed between two separators. Soluble polysulphides that are diffusing into the electrolyte are reduced on the stainless steel wire and the cumulative charge in the potential range between $2.25 \mathrm{~V}$ and $1.5 \mathrm{~V}$ versus platinum is used for the quantitative analysis. ${ }^{32}$ At first, we measured the elemental carbon/S based composite and lithium with the electrolyte solution of 1 M LiTFSI in sulfolane. Figure $7 \mathrm{a}$ (solid line) shows the discharge curve of the first cycle, and the corresponding CVs measured during the battery relaxation are shown in Figure $7 \mathrm{~b}$. A reduction peak at $\mathrm{U}_{\mathrm{p}} \approx 1.8 \mathrm{~V}$ versus platinum is observed in almost every $\mathrm{CV}$ measurement. An integration of this peak in the 2.25 $\mathrm{V}-1.5 \mathrm{~V}$ range gives the cumulative charge which is plotted in Figure 7a (blue spheres). This result shows that soluble polysulphides are formed at the beginning of the discharge. The partial cumulative charge associated with soluble polysulphides increases at the beginning, reaches the maximum at a nominal composition of $\mathrm{Li}_{0.3} \mathrm{~S}$, and then decreases, due to the disappearance of long chain polysulphides and formation of short chain polysulphides.

Then we measured the PAN/S-based composite in the same way as done for the carbon/S composite. Figure $7 \mathrm{c}$ (solid line) shows the discharge curve of the first cycle, and the corresponding CVs measured during the battery relaxation are shown in Figure 7d. As shown in Figure 7d we do not see any reduction peak at any voltage versus platinum and we do not have the reduction peak at all in the CV measurements. This result confirms our prediction that there are no soluble polysulphides formed, neither at the beginning of the discharge nor at lower voltages. The partial cumulative charge for the PAN/S composite was not calculated as no reaction peak in the $\mathrm{CV}$ cycles was observed.

The electrochemical measurements, TGA, and analytical observations indicate that the studied PAN/S composites did not contain any elemental $\mathrm{S}$ in the initial state nor was there any elemental $\mathrm{S}$ formation taking place during cycling. When PAN was heated to $300{ }^{\circ} \mathrm{C}$ along with elemental $\mathrm{S}$, it led to the dehydration of PAN by S. The highly polar $\mathrm{CN}$ functional groups in the PAN cyclized to form a thermally stable heterocyclic compound that was conductive in nature. The capacity from the PAN/S composite may be derived from lithium insertion into the anionic conjugated backbone in a polymer network, as is known to occur in electrically conducting polymers. ${ }^{37}$ One of the reasons for the observed capacity fading can be due to the degradation of the PAN/S host matrix and this can influence colouration of the electrolyte.

\section{Conclusion}

In this work, we successfully differentiate and demonstrate the process taking place in a PAN/S composite by comparing it with a carbon/S-based composite. Our analytical tools help us to obtain insight of the $\mathrm{Li}-\mathrm{S}$ bat- tery composites and understand the mechanisms inside the cell. The information provided by the in-situ analytical tools along with other experimental methods used in our work provide convincing evidence for the absence of elemental S in PAN/S composite initially or in the intermediate states of cycling. Needless to say that further experiments have to be done in this direction to understand PAN/S composite, as it is a promising composite for next generation batteries.

\section{Acknowledgements}

This research has received funding from the Slovenian Research Agency research program P2-0148 and the European Union Seventh Framework Program under grant agreement No.314515 (EUROLIS).

\section{References}

1. A. Manthiram, Y. Fu, Y-S Su, Acc. Chem. Res. 2013, 46, $1125-1134$.

2. S. Evers, L. F. Nazar, Acc. Chem. Res. 2013, 46, 1135-1143.

3. J. Wang, S. Y. Chew, Z. W. Zhao, S. Ashraf, D. Wexler, J. Chen, S.H. Ng, S. L. Chou, H. K. Liu, Carbon 2008, 46, 229-235.

4. Y.-S. Su, A. Manthiram, Nat. Commun. 2012, 3, 1166-1169.

5. Y. V. Mikhaylik, J. R. Akridge, J. Electrochem. Soc. 2004, 151, A1969-A1976.

6. L. Yin, J. Wang, F. Lin, J. Yang, Y. Nuli, Energy Environ. Sci. 2012, 5, 6966-6972.

7. S. S. Zhang, J. Power Sources 2013, 231, 153-162.

8. C. Zhang, H. B. Wu, C. Yuan, Z. Guo, X. W. Lou, Angew. Chem. Int. Ed. 2012, 51, 9592-9595.

9. Y.-S. Su, A. Manthiram, Chem. Commun. 2012, 48, 88178819.

10. S. Dörfler, M. Hagen, H. Althues, J. Tübke, S. Kaskel, M. J. Hoffmann, Chem. Commun. 2012, 48, 4097-4099.

11. J. Guo, Y. Xu, C. Wang, Nano Lett. 2011, 11, 4288-4294.

12. H. Wang, Y. Yang, Y. Liang, J. T. Robinson, Y. Li, A. Jackson, Y. Cui, H. Dai, Nano Lett., 2011, 11, 2644-2647.

13. L. Ji, M. Rao, H. Zheng, L. Zhang, Y. Li, W. Duan, J. Guo, E. J. Cairns, Y. Zhang, J. Am. Chem. Soc. 2011, 133, 1852218525.

14. S. Evers, L. F. Nazar. F, Chem. Commun. 2012, 48, $1233-$ 1235.

15. M. U. M. Patel, N. D. Luong, J. Seppälä, E. Tchernychova, R. Dominko, J. Power Sources 2014, 254, 55-61.

16. Y. Yang, G. Yu, J. J Cha, H. Wu, M. Vosgueritchian, Y. Yao, Z. Bao, Y. Cui, ACS Nano 2011, 5, 9187-9193.

17. F. Wu, J. Chen, L. Li, T. Zhao, R. Chen, J. Phys. Chem. C 2011, 115, 24411-24417.

18. L. Xiao, Y. Cao, J. Xiao, B. Schwenzer, M. H. Engelhard, L. V. Saraf, Z. Nie, G. J. Exarhos and J. Liu, Adv. Mater. 2012, 24, 1176-1181. 
19. C. Lai, X. P. Gao, B. Zhang, T. Y. Yan, Z. Zhou, J. Phys. Chem. C 2009, 113, 4712-4716.

20. X. L. Ji, L. F. Nazar, J. Mater. Chem. 2010, 20, 9821-9826.

21. J. Wang, J. Yang, C. Wan, K. Du, J. Xie, and N. Xu, $A d v$. Funct. Mater. 2003, 13, 487-492.

22. J. Wang, J. Yang, J. Xie, N. Xu, Adv. Mater. 2002, 14, $963-$ 965.

23. M. Z. Jacobson, Energy Environ. Sci. 2009, 2, 148-173.

24. P. G. Bruce, S. A. Freunberger, L. J. Hardwick, J.-M. Tarascon, Nat. Mater. 2012, 11, 19-30.

25. X. Yu, J. Xie, Y. Li, H. Huang, C. Lai, K. Wang, J. Power Sources 2005, 146, 335-339.

26. X. G. Yu, J. Y. Xie, J. Yang, K. Wang, J. Power Source 2006, 132, 181-186.

27. S. Pejovnik, R. Dominko, M. Bele, M. Gaberscek, J. Jamnik, J. power sources, 2008, 184, 593-597.

28. X. G. Yu, J. Y. Xie, J. Yang, H. J. Huang, K. Wang, Z. S. Wen, J. Electroanal. Chem. 2004, 573, 121-128
29. X. M. He, W. H. Pu, J. G. Ren, L. Wang, J. L. Wang, C. Y. Jiang, C. R. Wan, Electrochim. Acta, 2007, 52, 7372-7376.

30. J. Fanous, M. Wegner, J. Grimminger, A. Andresen, M. R. Buchmeiser, Chem. Mater. 2011, 23, 5024-5028.

31. L. Wang, X. He, J. Li, J. Gao, J. Guo, C. Jiang, C. Wan, J. Mater. Chem. 2012, 22, 22077-22081.

32. M. U. M. Patel, R. D-Cakan, M. Morcrette, J-M. Tarascon, M. Gaberscek, and R. Dominko, ChemSusChem 2013, 6, 1177-1181.

33. R. Dominko, R. D. Cakan, M. Morcrette, J.-M. Tarascon, Electrochem. Commun. 2011, 13, 117-120.

34. M. U. M. Patel and R. Dominko, ChemSusChem. 2014, 7, 2167-2175.

35. J. Fanous, M. Wegner, M. B. M. Spera, M. R. Buchmeiser, J. Electrochem. Soc. 2013, 160, A1169-A1170.

36. L. Wang, X. He, J. Li, M. Chen, J. Gao, C. Jiang, Electrochimica Acta 2012, 72, 114-119.

37. J. L. Bredas, R. Silbey, D. S. Boudreaux, R. R. Chance, J. Am. Chem. Soc. 1983, 105, 6555-6559.

\section{Povzetek}

Litij žveplovi akumulatorji predstavljajo novo generacijo akumulatorjev, kjer je poleg višje energijske gostote pričakovati tudi nižjo ceno. Ena izmed večjih težav, ki preprečuje njihovo komercializacijo, so topni polisulfidi, ki pospešijo degradacijo in upad kapacitete akumulatorja. Žveplo kovalentno vezano v organsko matriko (npr. v poliakrilonitril) izkazuje podobne elektrokemijske lastnosti in je eden izmed alternativnih katodnih materialov za litij žveplove akumulatorje. V tem članku smo primerjali elektrokemijske karakteristike kovalentno vezanega in prostega žvepla ter mehanizem delovanja, ki smo ga preučevali s pomočjo dveh in-situ analiznih metod. Uporaba in-situ UV-Vis spektroskopije in štiri elektrodne Swagelok celice pokaže, da v primeru kovalentno vezanega žvepla nimamo težav s topnimi polisulfidi. 